\title{
Just Transition as a Tool for Preventing Energy Poverty among Women in Mining Areas-A Case Study of the Silesia Region, Poland
}

\author{
Olga Janikowska ${ }^{1, *}$ and Joanna Kulczycka ${ }^{2}$ \\ 1 Mineral and Energy Economy Research Institute of the Polish Academy of Sciences, ul. J. Wybickiego 7A, \\ 31-261 Kraków, Poland \\ 2 Faculty of Management, AGH University of Science and Technology, Mickiewicza 30, 30-059 Cracow, Poland; \\ kulczycka@agh.edu.pl \\ * Correspondence: olgajan@min-pan.krakow.pl
}

check for updates

Citation: Janikowska, O.; Kulczycka, J. Just Transition as a Tool for Preventing Energy Poverty among Women in Mining Areas-A Case Study of the Silesia Region, Poland. Energies 2021, 14, 3372. https:// doi.org/10.3390/en14123372

Academic Editor: Ben McLellan

Received: 29 April 2021

Accepted: 1 June 2021

Published: 8 June 2021

Publisher's Note: MDPI stays neutral with regard to jurisdictional claims in published maps and institutional affiliations.

Copyright: (c) 2021 by the authors. Licensee MDPI, Basel, Switzerland. This article is an open access article distributed under the terms and conditions of the Creative Commons Attribution (CC BY) license (https:// creativecommons.org/licenses/by/ $4.0 /)$.

\begin{abstract}
The inevitable energy transformation can be perceived as an opportunity and as a threat to the actions undertaken to prevent energy poverty in European mining regions. Silesia is a special exemplification of the European region whose economy has been based on coal industry for centuries. There are still about 70,000 miners and coal is also widely used for heating households. Based on developed map of jobs lost in mining and related industry and the demographic and social data the proposal of activities addressed to different group of people has been created. It was also indicated that energy poverty in Poland mainly concerns households inhabited by single women. Therefore, the major conclusion of the paper is postulated that the Just Transition strategy should be extended by issues strictly related to the situation of women in the future labor market. Additionally, the concept of a special hub for women, whose aim would be professional activation of women of various age groups, has been introduced.
\end{abstract}

Keywords: coal; energy poverty; just transition; women; sustainable development goal; gender; employment

\section{Introduction}

Energy poverty has been identified in both developing and developed countries. It should be underlined that if energy poverty is defined as limitation of choice possibilities, it indicates that those who suffer this kind of poverty are a priori excluded not only from the possibility of the fulfilment of basic needs such as home heating or cooling and home cooking [1-5]. What is even more disturbing, they are excluded from other important elements that are necessary for individual development $[6,7]$. These include, above all, health, education, access to information, and participation in politics [8-10]. Energy poverty can have impact on heating or cooling a home, and also on health, education, access to information, and participation in politics. Energy poverty is a contributing factor in other types of poverty, and it can be perceived as one of the major challenges of the 21st century. It needs to be expected that in conditions of the absence of, or insufficient public policy support for those who suffer energy poverty [11-13], the level of energy poverty in Poland, especially in the Silesian Region, will increase as a result of the proposed legal regulations and the resulting requirements. Changes in the mining industry will effect on the employment structure in Silesia; additionally, in the near future, there will be a ban on the use of coal for heating households. Although it would affect all those who suffer energy poverty, it should be underlined that four times more households in energy poverty in Poland are occupied by single women than by a full family [2]. According to estimates the highest percentage of energy poverty in Poland is detected in the South-East part of the country $(21-29 \%)$. The lowest is in the North but also in two mining regions: Ślaskie and 
Dolnośląskie voivodships (8-12\%). In the near future, energy poverty in Poland, and in particular in the Silesia Region, will be influenced by two key factors. Firstly, transition to a decarbonized economy as 74,500 people work in the hard coal mining sector. Secondly, the Energy Performance of Buildings Directive, which proposes that the construction sector should not emit any carbon dioxide by 2050, but rather be carbon neutral. Additionally, all buildings in the European Union are to be decarbonized by 2050.

According to the Sustainable Development Goal (SDG) number 5: Gender equality, it is especially important to support and empower women and girls, as it would result in economic growth. What should be strongly underlined, is that although more and more women are present on the labor market, still in some regions women are deprived equal working rights. In this paper we are focusing on Just Transition, which is defined as transition of the workforce and the creation of decent work and quality jobs in accordance with nationally defined development priorities [14], and we claim that it should be a tool for preventing energy poverty among women. The Silesian Region was chosen due to its specificity in the role and place of women. For many years men in the region were professionally active and the miner's "honor" prevented his wife from being employed [15]. Additionally, the availability of jobs almost exclusively in the mining industry permanently consolidated the cultural division of social roles, at the same time the educational level of Silesia's women was rather poor. These historical premises, at some point, are present in the cultural code of Silesia. There is a concern that the region's profound economic transformation might result in structural unemployment, and, thus, deterioration of the material situation of Silesian women, which will result in energy poverty. As there is a clear relationship between access to energy and poverty, a more detailed analysis and prognosis are needed for people who live in extreme poverty, especially for women. It is very important to ensure proper financial and social support, which is foreseen with Just Transition and other restructuring funds [16].

In this article, we try to examine what changes will take place in the near future on the Silesian labor market and how they will affect the situation of women and energy poverty. We postulate that Just Transition should be a tool for preventing energy poverty among women in mining areas, and that a tailored program should be dedicated to women working in mining (about $10 \%$ ) as a significant transformation is foreseen which will phase out coal mining in Poland by 2049.

\section{Materials and Methods}

Firstly, the search was conducted through both the commonly used technique of web research of literature and the review of academic interdisciplinary databases including Scopus and Google Scholar. The key words used in the search were "energy poverty", "just transition", and "women". It was shown that one of the most common approaches to defining energy poverty is understating the term as lack of access to a modern energy service, such as a situation where a household cannot afford an energy service or the energy itself to provide basic daily needs such as: heating or cooling, cooking, lighting [3-5,15]. Additionally, energy poverty can be seen as the limit in accessing environmentally friendly, good quality, safe, and affordable energy services [6]. The research pointed out that there is a clear relationship between access to energy and poverty. Therefore, the next step was to look at statistical data to identify the maximum number of coal workers employed in the EU and to compare it with future green job opportunities, with a focused on future job possibilities for women. The next part of the research concerned the energy restructuring in Poland. It was shown that the role of hard coal in the Polish energy sector will gradually decrease. Taking into consideration the multiplier effect in research, a map of jobs lost to mining was divided into areas closer to the mines and the more distant surrounding areas. The last part of the research is focusing on the Silesian Region; therefore, the next step was to look at statistical data with a special focus on the potential for creating new jobs and the role of women on the future labor market. The methodology adopted in this work is presented in Figure 1. 


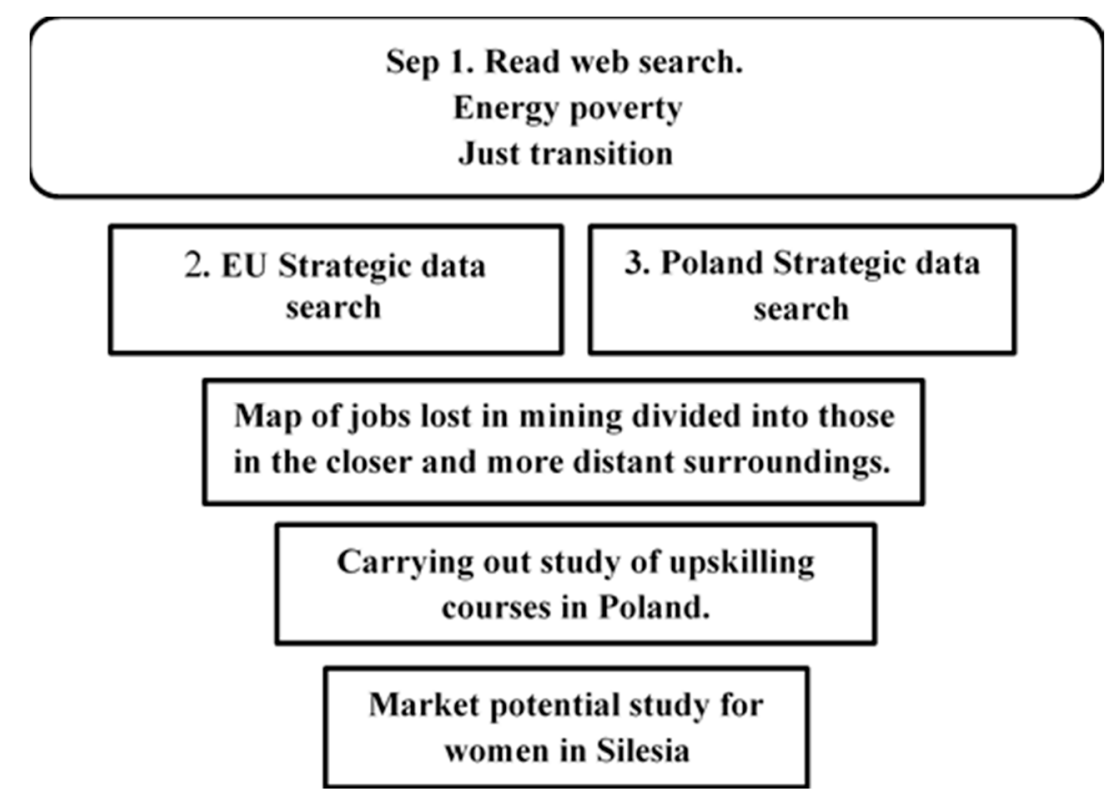

Figure 1. Algorithm for recognizing the market potential for Silesian women developed in this study.

During the critical analysis of literature, the research gap on the role and place of woman during the job restructuration in Silesia Region was identify. In the paper we suggest that energy policy is top-down policy whereas Just Transition should be a bottomup policy, which means that the transformation processes should engage civil society and social capital. The paper represents a new approach to the Just Transition issues in the Silesia region. Analyze of the development of the national policy indicates, that since the very beginning to of the mining restructuration in Poland, there was a lack of reskill programs dedicated for a working at the mine industry women. During the research correlation between transition to a low carbon economy and energy poverty of women in Silesia region was indicated. During the transformation many jobs will be lost in the region, but still as we point out the social group who suffers the energy poverty in Poland are mostly single women. Due to a specific cultural tradition of the region married women usually stop they professional development to be a full time housewife's. During the research we have identify the knowledge gap, as aspects of the future situation of women on the labor market in Poland in relationship with the energy poverty has not been solved by existing studies. This is why we hope this paper would open the discussion on future place of women on the Silesian labor market after the energy transformation.

\section{Results}

Energy poverty is a phenomenon that occurs among the inhabitants of developed and developing countries, therefore, combating it is important in terms of social welfare [17]. With increased concern about climate change, analyses focusing on energy consumption, energy structure, and the energy market lie behind many policies. Energy poverty is related more to income poverty than to socio-economic inequalities [18-21]. In the EU, detailed analysis and assessment has been provided annually. The newest EU document on energy prices and costs in Europe shows that the annual increase in the price of electricity in the European Union has increased by $2.3 \%$ since 2010. This means that, taking into account inflation over the last decade, payable electricity is $9 \%$ more expensive. Moreover, in 2018 the poorest European households still spent $8.3 \%$ of their total expenditure on energy. Individual consumers who will take a part in transformation, on one hand would be protected from the growing energy prices, but on the other they are going to be fortified to become an active the energy market. However, even though the price of many renewable energy installations has dropped significantly, and more funds are available to support 
individual consumers, there are many individual houses, especially in Poland, where coal is widely used for heating.

The coal dominates the power sector in Poland, however with significant dependence on external supplies of natural gas and almost full dependence on external supplies of crude oil, the aspects of energy safety, transformation, and clean air have been usually the most important part of Polish energy policy for decades. The most important documents are as follows:

- 1997 The act of 10 April;

- 1997 The Energy Law (it has been often updated in last years as the consequence of the amendment of other legal in scope adopted primarily due to the need to adjust the Polish legal order to EU law requirements);

- 1990 Foundation of the energy policy of Poland for 1990-2010;

- 1995 Establishment of an energy policy until 2010;

- 2000 Assumptions of Poland's energy policy until 2020;

- 2002 Evaluation of the implementation and correction of the assumptions of energy policy until 2020;

- 2005 Energy policy of Poland until 2025;

- 2009 Energy policy of Poland until 2030;

- 2021 Energy policy of Poland until 2040 [22-25].

Poland's energy policy until 2040 defines the framework for energy transformation and is a response to the EU climate policy. The policy takes into account the scale of the challenges related to the adaptation of the national economy to the EU regulatory conditions related to the 2030 climate and energy goals, the European Green Deal, the COVID economic recovery plan and the pursuit of climate neutrality in line with national opportunities, as contribution to the implementation of the Paris Agreement. The energy policy in Poland was updated on the regular base, still up till now there is a lack of social emphasis in the policy, as it focuses mainly on energy safety, transformation towards RES and minimalization of the environmental impact. This is why we claim that Just Transition calls for in printing social challenges into energy policy. The core of energy policy of Poland until 2040 are illustrated in Figure 2.

With the new Energy Policy 2040 [22], approved in February 2021, a diminishing share of coal is foreseen in energy generation and heating. The main goals of policy is: ensuring energy security, safeguarding energy poverty, providing support for environmental protection, ensuring the safety of environmental controls, ensuring the safety of environmental controls, ensuring the safety of environmental controls, ensuring the safety of environmental controls, ensuring the safety of environmental controls, ensuring the safety of environmental controls, ensuring the safety of environmental controls, ensuring the safety of environmental controls. This policy is in line with the assumptions of the legislative package entitled 'Clean Energy for All Europeans' [26]. According to the European Commission, energy poverty cannot be capture only by a one indicator. Energy poverty is a phenomena which is correlated with following negative consequences such as; health and mental problems. As there is a lack of standardized definition of energy poverty, that is why member states should develop their own criteria according to their national context. What needs to be underlined in 2018 is that $6.8 \%$ of Europeans living in the private households could not keep up with their energy bills. The fact that energy and fuel poverty is still one of the biggest challenges of the 21st century is also widely discussed in the literature [1-6,9-14]. It covers technological, economic, and social aspects and also natural inequalities [27] which underline the fact that, still despite of the technological and scientific development of the world, quality of life does not follow. Therefore, energy poverty is identified both in developing countries, and developed countries. It should be carefully monitored in Poland as significant transformation is foreseen due to the phasing out of coal mining by 2049. 


\begin{tabular}{|c|c|c|}
\hline \multirow{3}{*}{ Pillars } & \multicolumn{2}{|l|}{ Pillar I. Just Transition } \\
\hline & \multicolumn{2}{|c|}{ Pillar II. Zero-emision Energy system } \\
\hline & \multicolumn{2}{|c|}{ Pillar III. Good air quality } \\
\hline $\begin{array}{l}\text { SPECIFIC OBJECTIVE } 1 . \\
\text { Optimal use of own energy } \\
\text { sources }\end{array}$ & $\begin{array}{l}\text { SPECIFIC OBJECTIVE } 2 \text {. } \\
\text { Development of electricity } \\
\text { generation and network } \\
\text { infrastructure sources }\end{array}$ & $\begin{array}{l}\text { SPECIFIC OBJECTIVE } 3 . \\
\text { Diversification of supplies } \\
\text { and expansion of the } \\
\text { network infrastructure of } \\
\text { natural gas, crude oil and } \\
\text { liquid fuels }\end{array}$ \\
\hline $\begin{array}{l}\text { STRATEGC PROJECT } 1 . \\
\text { Transformation of coal } \\
\text { regions }\end{array}$ & $\begin{array}{l}\text { STRATEGC PROJECT 2A. } \\
\text { Capacity market, } \\
\text { STRATEGC PROJECT 2B. } \\
\text { Implementation of smart } \\
\text { power grids }\end{array}$ & $\begin{array}{l}\text { STRATEGC PROJECT 3A. } \\
\text { Construction of the Baltic } \\
\text { Pipe STRATEGC } \\
\text { PROJECT 3B.Construction } \\
\text { of the second line of the } \\
\text { Pomeranian Pipeline }\end{array}$ \\
\hline \multicolumn{2}{|c|}{$\begin{array}{l}\text { SPECIFIC OBJECTIVE } 4 . \\
\text { Development of energy markets }\end{array}$} & $\begin{array}{l}\text { SPECIFIC OBJECTIVE } 5 \text {. } \\
\text { Implementation of nuclear } \\
\text { power }\end{array}$ \\
\hline \multicolumn{2}{|c|}{$\begin{array}{l}\text { SPECIFIC PROJECT } 4 \mathrm{~A} \text {. } \\
\text { Implementation of the Action Plan (aimed at increasing } \\
\text { cross-border electricity transmission capacity) } \\
\text { STRATEGC PROJECT } 4 \mathrm{~B} \text {. } \\
\text { Gas hub }\end{array}$} & $\begin{array}{l}\text { STRATEGC PROJECT } 5 . \\
\text { Polish Nuclear Power } \\
\text { Program }\end{array}$ \\
\hline $\begin{array}{l}\text { SPECIFIC OBJECTIVE } 6 . \\
\text { Development of } \\
\text { renewable energy sources }\end{array}$ & $\begin{array}{l}\text { SPECIFIC OBJECTIVE } 7 . \\
\text { Development of district } \\
\text { heating and cogeneration }\end{array}$ & $\begin{array}{l}\text { SPECIFIC OBJECTIVE \&. } \\
\text { Improvement of energy } \\
\text { efficiency }\end{array}$ \\
\hline $\begin{array}{l}\text { STRATEGC PROJECT } 6 . \\
\text { Implementation of } \\
\text { offshore wind energy }\end{array}$ & $\begin{array}{l}\text { STRATEGC PROJECT 2A. } \\
\text { Development of district } \\
\text { heating }\end{array}$ & $\begin{array}{l}\text { STRATEGC PROJECT \&. } \\
\text { Promotion of the } \\
\text { improvement of energy } \\
\text { efficiency }\end{array}$ \\
\hline
\end{tabular}

Figure 2. The core of energy policy of Poland until 2040, based on energy policy of Poland until 2040. Source: Energy policy of Poland until 2040.

Most documents emphasize that the ending of hard coal production in individual mines will relate to the provision of different social guarantees to workers, but that such a transition could also have a significant impact on many households using coal for heating. As there is a clear relationship between access to energy and poverty, there is a need for a more detailed analysis of people who live in extreme poverty and accompanying recommendations considering structural changes associated with the closing of the mining sector and the identification of people's needs and choices. According to Sen [27], "development consists of the removal of various types of unfreedoms that leave people with little choice and little opportunity of exercising their reasoned agency". He claims that the enhancement of freedoms allows people to lead lives that they have reason to value. According to his theory, the emphasis that has been put on gross domestic product (GDP) as the basic measure of development has been inadequate, and that is why his theory of development goes far beyond understanding development just as maximizing income per capita. He argues that measures of development should be followed by factors such as political freedoms, high standard of living, ability to access social goods, such as health care, education, reduction in hunger and premature death. Those are the basic conditions of development. Sen's contribution to the theory of development was a factor in the development of the Human Development Index (HDI), which is composed of the following indicators: life expectancy, education, and income per capita. 
There is a strong correlation between energy poverty defined as the absence of sufficient choices and Sen's development theory as the core of development theory is not being excluded from those options that enable one to choose and obtain welfare in its broadest sense. If energy poverty is defined as the absence of sufficient choice, it indicates that those who suffer this special kind of poverty are a priori not only excluded from the possibility of fulfilling basic needs such as home heating or cooling and home cooking but, and this is even more disturbing, they are also excluded from other important elements that are necessary for individual development, and these are above all health, education, access to information, and participation in politics. In this context energy poverty is an obstacle to the development process, understood in line with Sen's theory as expanding people's freedom. Additionally, energy poverty reinforces development disproportions, which is especially important in terms of global justice theory $[28,29]$ which is becoming a more and more important principle of political agendas.

The first difference revealed is a different distribution of the number of households ordered according to the number of men or women who belong to them. One of the types of households which are most severely burdened with expenditure on energy carriers are households run by a single person [30]. There are four times more energy poor households inhabited only by women (one or more) than households inhabited by only by men (one or more)-in the proportion of 481,500 to 121,200 . Energy poor women, on the other hand, more often live-in households where there are no men (usually they are single-person households). A greater share of energy poor women, compared to the share of energy poor men within these groups, can be observed in the case of households: inhabited by one person (women: $11.3 \%$, men: $3.2 \%$ ); pensioners (women: $7.5 \%$, men: $5.4 \%$ ); retirees (women: $21.6 \%$, men: $16.5 \%$ ), single mothers with dependent children and other persons (women: 6.4\%, men: $4.4 \%$ ); people living in multi-family buildings (women: $45.5 \%$, men: $41.3 \%$ ); people living in apartments with an average area of $30-60 \mathrm{~m}^{2}$ (women: $37.2 \%$, men: $34 \%$ ) [31]. An empirically significant negative causal relationship was found between the indicators of multidimensional energy poverty and health for women [32].

\subsection{The Future Labor Market in Coal Sector}

The decarbonization of the EU-27 is expected to result in the loss of approximately 76,000 jobs in coal mines and plants by 2025; the number is expected to double with more than 154,000 job losses projected by 2030 [14]. The withdrawal of coal will have different effects in different regions, it is making sure that no one is left behind, a 'just transition' for workers and communities as the world's economy responds to climate change was included as part of the 2015 Paris Agreement on climate change [14]. In the EU, coal infrastructure is present in 108 regions, and according to estimates the coal sector currently provides 237,000 jobs, mainly in coal mining - 185,000 jobs. The largest number of people employed in the coal sector is found in the following European Union countries: Poland, Germany, the Czech Republic, Romania, Bulgaria, Greece, and Spain-this gives nearly 200,000 jobs directly related to coal, and it is in these regions that the largest job losses can be expected.

The transition to a decarbonized economy is a chance for the further development of green jobs, which refer to those with indirect or direct influence on environmental benefits [32]. There are forecasts which focus on green jobs according to their own definition, i.e., OECD, EU, UNEP, ILO. According to the ILO, changes in energy production can create 18 million jobs throughout the world economy. Employment in the EU-28's environmental economy rose from 2.8 million full-time equivalents (FTE) in 2000 to 4.5 million full-time equivalents in 2016 (ILO, 2018). Those include a shift towards renewable energy sources, as they have the potential to generate employment opportunities. Renewable energy production is more labor intensive than conventional energy production in delivering the same amount of energy output [33]. Employment in the renewable energy sector (wind, photovoltaic, biomass) can be divided into construction and operation. Directly and indirectly, there is about 1.51 million employees in renewable energy sector in the 
European Union, what represents a gross growth of 67,000 jobs $(+4.6 \%)$, of which Poland's increase is 11,900 jobs (16\%) between 2017 and 2018 [31-38].

The role of hard coal in the Polish energy sector will gradually decrease. The transition to a low-carbon economy in the coming years will be a major challenge both for the country and for regions with a mining tradition. Poland will have to face not only the energy transformation, but also a significant transformation of the labor market. In 2018, Poland adopted its strategy for the coal sector in Poland until 2030, in 2019 Poland approved its National Energy and Climate Plan for the years 2021-2030 (NECP) which stipulated its objectives relating to increased energy efficiency and decarbonization, and in February 2021 it adopted Energy Policy 2040 in which a diminishing role of coal in energy generation and heating is foreseen, but in which also activities connected with Just Transition and a reduction in energy poverty are emphasized.

What should be taken into consideration during planning for the Just Transition is the multiplier effect, which is defined as the situation in which as the situation in which a rise of spending generates an increase in national income, which is bigger than initial amount spent. The employment multiplier effect defines the quantity of direct, indirect, and induced jobs created or lost in the area, which can be observed in Figure 3. The mining multiplier effect means that each loss of a mining job will cause several more workers to lose their jobs. At the end of December 2019 there were 83,297 people employed in hard coal mining in Poland, 64,259 of them working underground. A total of approximately 400,000 employees are employed in the mining facilities sector. In total, that provides nearly half a million jobs and, thus, it confirms the popular slogan that one job in mining generates three or four jobs in its surroundings. Job reduction in mining is associated with a reduction in jobs in sectors providing goods and services for mines. The number of employees associated with the activity undertaken by the mining sector is 56,700 , i.e., about $0.4 \%$ of the number of employees in Poland.

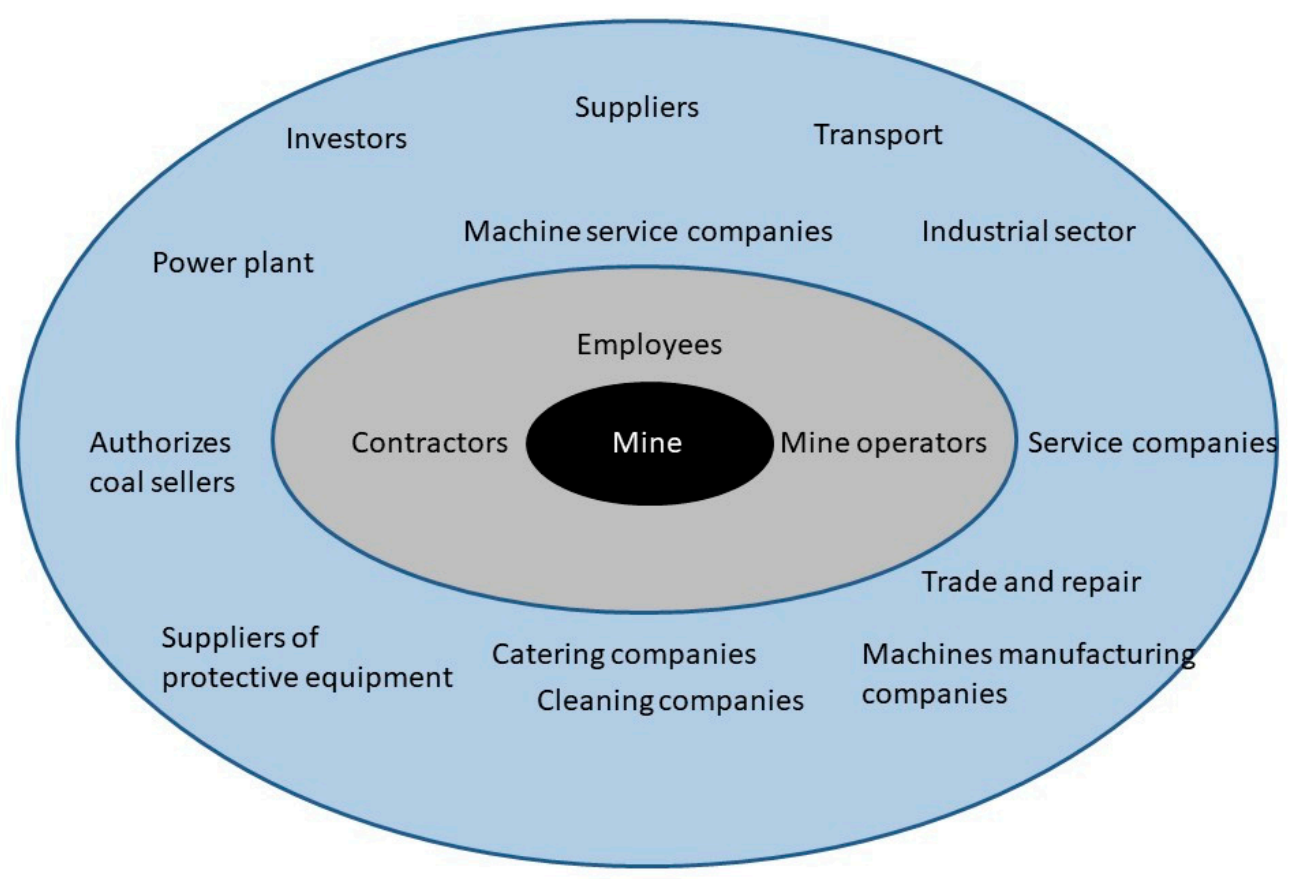

Figure 3. Jobs associated with mining divided into those in the close vicinity and those in the more distant surrounding area.

In accordance with the principles of Just Transition, the energy transformation process should be based on the following tools:

- Retirement;

- leaving mining; 
- change of position inside the plant;

- relocation to another establishment;

- $\quad$ shifting to work on closing the mine;

- re-qualification for a profession other than mining.

In the terms of energy poverty, the potential for re-qualification for a job in the renewable energy sector should be a priority, but the requalification of women should also be taken into consideration. The relationship between national energy policy, which is divided into 6 transformation periods and employment rate was illustrated in Figure 4.

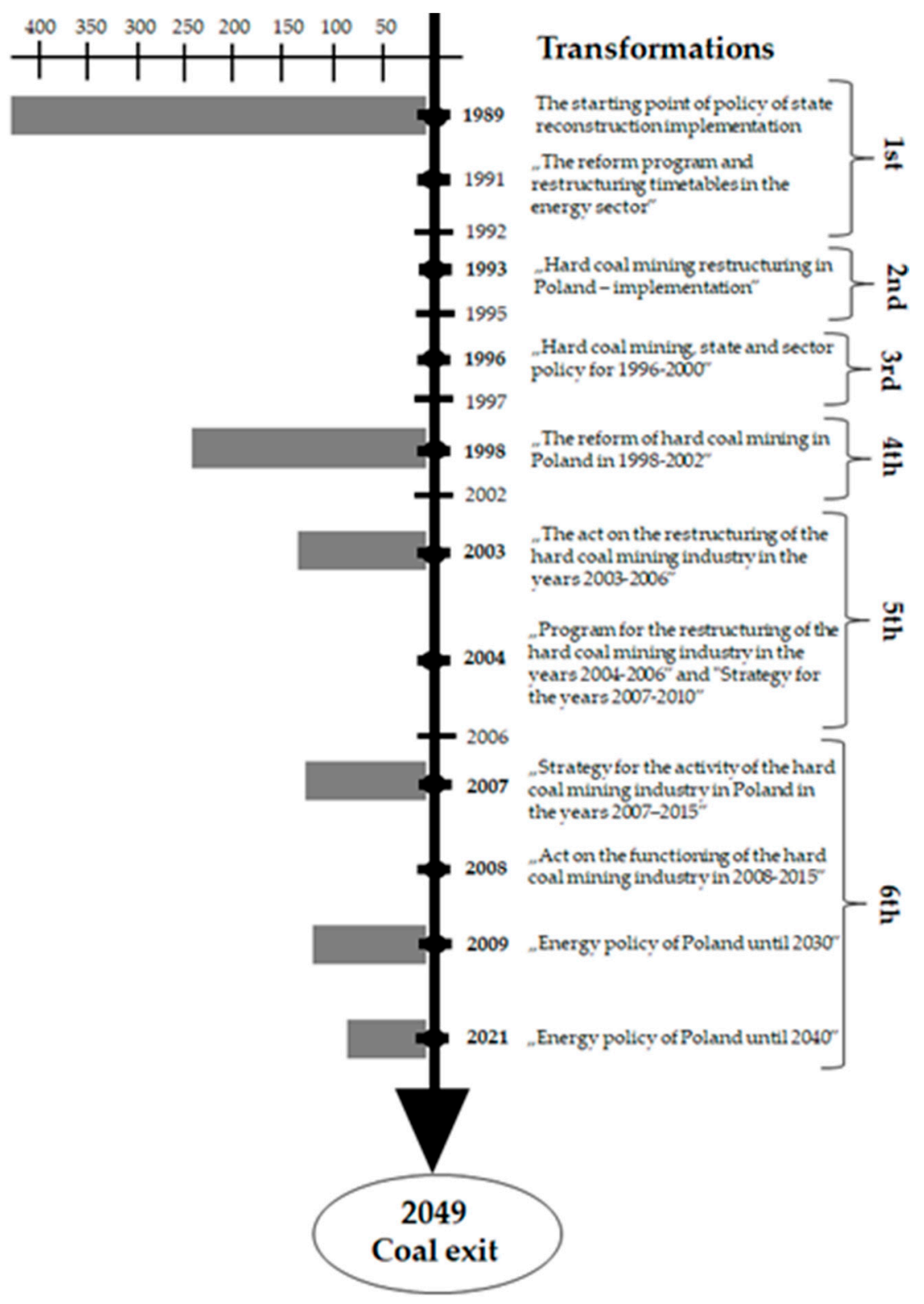

Figure 4. The relationship between national energy policy and employment rate.

\subsection{Just Transition in the Silesian Voivodeship}

The Silesian Voivodeship is in southern Poland. It is one of the smallest ( $3.8 \%$ of Poland) but the most densely ( $12 \%$ of Poland) populated voivodeship in Poland, where over $77 \%$ of region's population live in cities and towns. Moreover $77.6 \%$ of the population aged 25 to 54 years, and over $19 \%$ of the population is within the economically postproductive age. It is also the most industrial region in the country, almost $12.4 \%$ of the Polish GDP is being generated here what ranks the region on the second position within 
the country. Even though most of the Polish coal is mined in Silesia, the role of mining has been diminishing. However, 74,500 workers are employed in the hard coal mining industry mainly men, creates $7 \%$ of the vale added in the region. It is estimated that 4 time more, i.e., 280,000 employees are employed in the mining facilities sector, of which many women.

The process of closing mines in the Silesia Region planned will result in wide-ranging social and economic changes. The Silesia is currently at a turning point in its transformation, and 2021 is a year of key decisions for the future of the region and its inhabitants. The course of transformation will put pressure on the local economy, the labor market and social issues. Therefore, both the regional authority and the Polish government are working on plan of transformation, focusing mainly on possibility of creation jobs in different sectors, including renewable energy.

The declaration of the shutdown of the mining industry, concluded in an agreement between the government and the trade unions, begins a new stage in the comprehensive transformation process. The industries with a chance of replacing mining in the future are construction, industrial processing, and energy, they are part of the region's specialization, and the required skills, knowledge, and competences are part of the education profile of people employed in the mining industry. Other activities that may offer attractive jobs are logistics and remediation activities [39-42]. According to preliminary estimates, approximately $24-41,000$ jobs may be created in the industries cited by 2030 . Another $43-55,000$ jobs may be created in activities diversifying the regional economy, such as development of business services. The creation of new jobs should be supported by strong incentives for investors who are ready to locate their activities in mining communes, support offered to existing and new entrepreneurs for the creation of high-quality jobs, support for the development of science and new education courses, and appropriate spatial policy.

According to the data, the number of unemployed people in Silesia who were registered with county labor offices in December 2020 totaled to 91,032 people and was 1545 people higher than in the previous month. Women predominate $(51.4 \%)$ in the population of the unemployed in the Silesia Region (Statistics Research and Analysis Team). As of 31 December 2020, 49,851 unemployed women accounted for $54.8 \%$ of the total number registered (a month earlier, the corresponding share was similar and amounted to 54.9\%).

Men and women often work in different professions and industries and have different average wages and working hours. The reasons for this fact lie in both historical and biological conditions. It was mainly men who were present on the Polish labor market as women gradually entered it, a process which took place after World War II and which was related to the dynamic development of the economy. The share of women in the number of employees in Poland has been steadily increasing since 1950 (Figure 5).

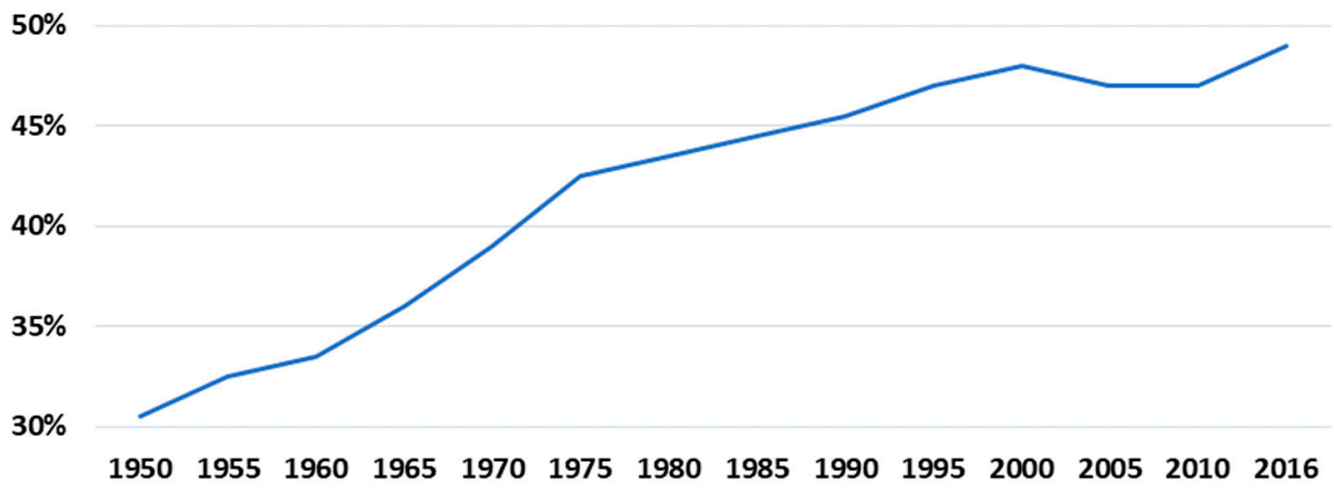

Figure 5. Share of women in the total number of employees in Poland, based on GUS, women and men in the labor market (2004-2018).

Sociological research conducted in the context of contemporary cultural changes, consisting in the weakening of the cultural pattern of pressure directed at women to see 
their role in life primarily in terms of being wives and mothers, indicates the barriers to the professional advancement of women that still exist, as well as the problems that result from combining social roles. This situation applies to women in Poland, especially women in the Silesia Region [43]. This is mainly due to the specific nature of the region. Traditionally, in the Silesian family, men played the role of breadwinner, and the miner's "honor" prevented his wife from working. An external factor influencing the role of women in Silesia was the almost exclusive availability of jobs in the mining industry, which permanently consolidated the cultural division of social roles. Additionally, one should consider that the qualifications of miners' wives were rather low-most of them had vocational education, a few had secondary education. When it comes to working women, before World War II, Silesian women mainly took up jobs in mines, steel mills, and factories. The zinc smelting industry employed the most women. In the 1940s and 1950s, women took up employment in industry, mostly performing auxiliary work. However, the living standards of Silesian families were mostly provided by male workers. In the 1960s, more and more girls graduated from vocational school, which triggered changes in the professional structure of the region. In the 1970s, the percentage of professionally active women increased, some sectors, such as trade, education, as well as health and social welfare were dominated by women. An important factor improving the education of women in Silesia was the establishment of the University of Silesia in 1968 which provided education in the humanities. The period of systemic transformation after 1989 subjected the Silesian family to a serious test. Phenomena such as loss of one's job, unemployment, and impoverishment affected Silesian families [15]. The employment structure with the division into gender between 2004 and 2018, can be seen in Figure 6.

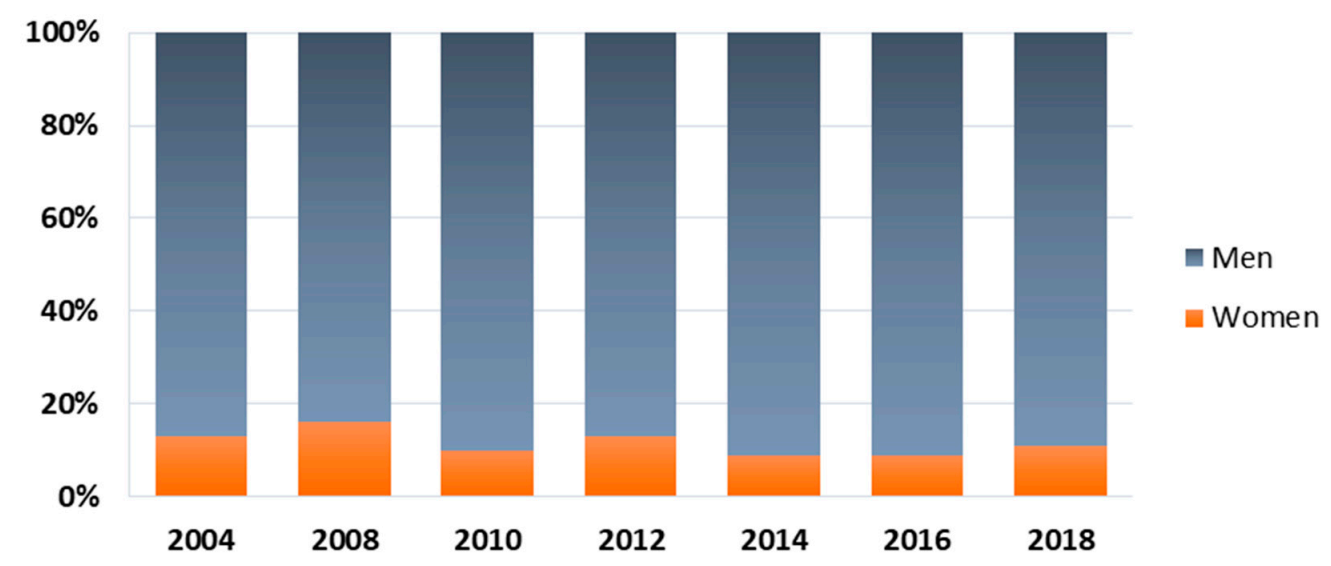

Figure 6. Mining and quarrying-employment with divisions into men and women, based on GUS, women, and men in the labor market (2004-2018).

In Poland, the ban on employing women underground in mines introduced in 1975 resulted from the Labor Code supplemented by executive regulations. At the time of Poland's accession to the European Union, the Polish labor law limited the scope for employing women underground in mines; it did not cover work performed in certain legal situations (permitted work). After Poland's accession to the European Union, the maintenance or lifting of this ban became an important problem, and its resolution depended on the outcome of proceedings pending before the European Court of Justice regarding Austrian regulations, which contain a prohibition like that in force in Poland.

\subsection{Silesia of the Future}

The process of restructuring Silesia should consider the fact that the core of Silesian identity is related to hard coal. The inhabitants of Silesia will also experience a profound cultural change, which affects the ethos of conscientious work, reliability, and love of family that is so important to the inhabitants of the region and which is the ethical code of the 
Silesian population. It is important that the reform takes place with public acceptance of its goals and of the stages in its implementation. It must be remembered that the cost of the necessary social changes is one of the issues that worries the inhabitants of Upper Silesia the most. The process of closing the mining industry is inevitable, but in the name of fairness, solidarity, and sustainable development, this process should be more closely linked with the process of supporting mining municipalities so that cities built on coal and for the coal industry, as compensation for incurred costs and losses (including environmental), receive post-industrial infrastructure to be used for scientific, educational, social, cultural, and commercial purposes.

Replacing coal will accelerate the development of renewable energy, energy storage technologies, and other technologies that stabilize the operation of the power system. The key challenge of a just transition will be the equal distribution of costs and benefits resulting from technological change. For the Silesia Region, this should mean replacing jobs in declining industries with jobs in modern industry and services, especially in industries related to energy transformation. It is necessary to carefully discern not only the needs but also the possibilities of new labor markets, so that they are best suited to the emerging modern economy, but also to take into account the age structure and education of women.

\section{Discussion}

According to the SDG, more precisely to goal number 5-Gender equality according to which ending all discrimination against women and girls is the priority in terms of human rights. What should be strongly underlined is that, despite the fact that women are present at the labor market, still in some regions there are significant inequalities, with women systematically denied the same working rights as men. In the era of late modernity, developed capitalism, and the democratic postulates of participation, a special place in the process of just transformation of Silesia should be devoted to women. The role women play in the future labor market should be defined. As part of Just Transition, a serious discussion about women's expectations of employment opportunities in restructuring areas should be considered. It is necessary to carefully discern not only the needs but also the possibilities of new labor markets, so that they are best suited to the emerging modern economy, but also to take into account the age structure and education of women. Counteracting the professional exclusion of women in Silesia is extremely important in the context of energy poverty. It is true that the analysis of the gender distribution in the population and in the group of the energy poor shows that they are almost identical, yet, despite the lack of differences between men and women in the percentage of energy poverty at the general level, differences can be noted in the distribution of results for gender depending on individual categories.

For many reasons, for the global, national, and regional market, the restructuring of the coal industry, and, thus, the socio-economic transformations in the Silesia Region, are inevitable. They are part of the study with zero emission future of the European Union. It is worth adding that this is not the first time Silesia will undergo restructuring. In the years 1990-2000, the process of restructuring of the hard coal mining industry commenced, which, since 1993, was implemented on the basis of economic and social assumptions of restructuring programs approved by the Economic Committee of the Council of Ministers. The economic changes in Poland after 1989 in the hard coal mining industry began with the restructuring of the management of this sector. In 1990, the structures supervising the mines were liquidated, the Hard Coal Community, which was established in place of the previously liquidated Ministry of Mining and Energy, ceased to function. Hard coal mines have become independent state-owned enterprises. In the years 1989-2000, employment in the hard coal mining industry decreased by 2600 thousand employees. In the years $1989-1992$, approximately 25,000 people left the mining industry annually. The high rate of decline in employment continued in the next two years (1993-1994). Employment decreased by 51,700 people, i.e., by $15.1 \%$. In the following years, the pace of reducing employment was lower, in total 45,100 employees left their jobs. In the years 1998-1999, as 
a result of the application of the Mining Social Package instruments, there was a significant increase in the number of employees leaving jobs. The total decrease in employment in two years amounted to 697,000 people. In 2000 , the decline in employment amounted to a further 18,600 employees. These changes caused several socio-economic problems, the consequences of which are felt in Silesia to this day.

Although Silesia is a region of Poland characterized by a low percentage of people suffering from energy poverty, it is also a region with a certain specificity. It is a region that is the largest mining area in Poland. In the perspective of energy poverty, which particularly affects single women living alone in Poland, it is extremely important in the transformation process to focus on women who will lose their jobs due to the changes or their working husbands will be subject to layoffs.

\section{Conclusions}

In this paper, we discuss energy transformation in Poland, and its influence on the energy poverty. As according to the data energy poverty in Poland mainly concerns households inhabited by single women, we are focusing on place and role of women in the future job market at Silesian Region. During working on the paper gap in research in this field was identified, what is especially important in the light of SDG 5.

An in-depth study on energy policy development pointed to the lack of sufficient social emphasis in the document strategy, as it is generally focused mostly on energy safety, transformation towards RES, and minimalization of the environmental impact. According to the authors there is a need to fulfil the mechanisms of Just Transition with a special agenda for the future place and role of women in new emerging job market. As it is single unemployed women who are in Poland the most vulnerable to energy poverty, we claim that a special hub for women as part of Just Transition should be created.

The number of women directly employed in mining in Poland is 7375 , if we take under consideration the number of women who works in the nearest surrounding of mines this number will increase by another 5015 (Figure 7). Still if we take under consideration multiplier effect, quantity of direct, indirect and induced jobs created $t$ in the area, we should multiply the total number of women employees in the mining sector by a factor of 4 . Moreover, when it comes to future occupational restructuring, it should be underline that the lowest percentage of women employed in mining is those who works underground. Therefore, future restructuring programs should be designed for a wide professional scale; from female workers, through administrative, cooks, engineers, and cleaners, etc.

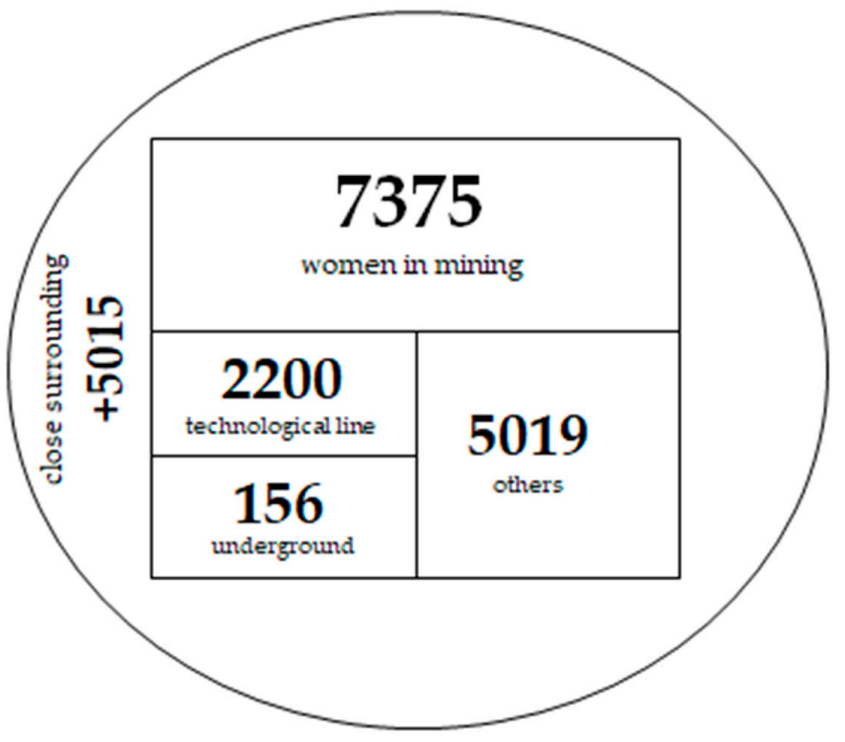

Figure 7. Number of women employed in mining, based on GUS, women, and men in the labor market (2004-2018). 
The aim of the hub, which is a form of preventive response to the future problems of women in Silesia, would be: assistance in reskill from mining to different forms of employment, assistance in contact with reskilling course providers, psychological support do not give up approach, training in re-enter labor market (e.g., support in CV creation, best practices for the job interview, dress code, how to use social media), cooperation with the reskilling course providers, engaging issues that affect the living standards of Silesian woman's, promotion of sustainable development approach, support on job reorientation, provide technical support, assistance and programs to educators, industry, and local government.

Author Contributions: Conceptualization, J.K. and O.J.; methodology, J.K. and O.J.; formal analysis, J.K. and O.J.; investigation, O.J.; resources, O.J.; data curation, J.K. and O.J.; writing—original draft preparation, O.J.; writing-review and editing, J.K.; visualization, O.J. All authors have read and agreed to the published version of the manuscript.

Funding: This research was funded by the Res-skill Project (Reskilling coal industry workers for the renewable energy sector), co-funded by the Erasmus + Program of the European Union and under subvention funds for the Faculty of Management and by program "Excellence Initiative-Research University" for the AGH University of Science and Technology.

Institutional Review Board Statement: Not applicable.

Informed Consent Statement: Not applicable.

Data Availability Statement: Not applicable.

Conflicts of Interest: The authors declare no conflict of interest.

\section{References}

1. Boguszewski, R.; Herudziński, T. Ubóstwo Energetyczne w Polsce; Pracownia Badań Społecznych SGGW: Warszawa, Polska, 2018; pp. 23-25.

2. Owczarek, D. (Nie)równy Ciężar Ubóstwa Energetycznego Wśród Kobiet i Mężczyzn w Polsce; ClientEarth: Warszawa, Polska, 2016; pp. 5-7.

3. Boardman, B. Fuel Poverty: From Cold Homes to Affordable Warmth; Belhaven Press: London, UK, 1991; pp. 1071-1072.

4. Bouzarovski, S.; Petrova, S.; Sarlamanov, R. Energy poverty policies in the EU: A critical perspective. Energy Policy 2012, 49, 76-82. [CrossRef]

5. Buzar, S. Energy Poverty in Eastern Europe: Hidden Geographies of Deprivation; Routledge: Surrey, UK, 2007 ; p. 47.

6. Reddy, A.K.N. Energy and Social Issues. In World Energy Assessment: Energy and the Challenge of Sustainability; United Nations Development Programme: New York, NY, USA, 2000; pp. 179-185.

7. Halkos, G.; Gkampoura, E.-C. Evaluating the effect of economic crisis on energy poverty in Europe. Renew. Sust. Energ. Rev. 2021, 144, 11. [CrossRef]

8. Bardazzi, R.; Bortolotii, L.; Pazienza, M.G. To eat and not to heat? Energy poverty and income inequality in Italian regions. Soc. Sci. 2021, 73. [CrossRef]

9. Selecting Indicators to Measure Energy Poverty. Available online: https://ec.europa.eu/energy/sites/ener/files/documents / Selecting\%20Indicators\%20to\%20Measure\%20Energy\%20Poverty.pdf (accessed on 2 September 2020).

10. Policy Report, Energy Poverty and Vulnerable Consumers in the Energy Sector across the EU: Analysis of Policies and Measures. 2015. Available online: https:/ / ec.europa.eu/energy/sites/ener/files/documents/INSIGHT_E_Energy\%20Poverty\%20-\%20 Main\%20Report_FINAL.pdf (accessed on 10 July 2020).

11. Bouzarovski, S. Energy Poverty. (Dis)Assembling Europe's Infrastructural Divide, 1st ed.; Springer Nature: London, UK, 2018.

12. Addressing Energy Poverty in the European Union: European State of Play and Action. Available online: https://www. energypoverty.eu/sites/default/files/downloads / publications/18-08/paneureport2018_final_v3.pdf (accessed on 10 January 2021).

13. The Health Impacts of Cold Homes and Fuel Poverty. Available online: http://www.instituteofhealthequity.org/resourcesreports / the-health-impacts-of-cold-homes-and-fuel-poverty/the-health-impacts-of-cold-homes-and-fuel-poverty.pdf (accessed on 10 July 2020).

14. Paris Agreement, United Nations. Available online: https://unfccc.int/sites/default/files/english_paris_agreement.pdf (accessed on 1 February 2021).

15. Swadźba, U. Śląskie wartości-praca, rodzina i religia: Geneza, trwanie i zmiany. Górnośl. Stud. Socjol. 2014, 5, $22-41$.

16. GUS. Kobiety i Mężczyźni na Rynku Pracy. 2018. Available online: http://eregion.wzp.pl/sites/default/files/kobiety_i_ mezczyzni_na_rynku_pracy_2018.pdf (accessed on 10 July 2020). 
17. Report from the Commission to the European Parliament, the Council, the European Economic and Social Committee and the Committee of the Regions. Available online: https:/ / ec.europa.eu/transport/sites/transport/files/legislation/com20190120.pdf (accessed on 10 July 2020).

18. Directive 2009/72/ECof the European Parliament and of the Council of 13 July 2009 Concerning Common Rules for the Internal Market in Electricity and Repealing Directive 2003/54/EC. Available online: https:/ / eur-lex.europa.eu/legal-content/EN/TXT/ PDF/?uri=CELEX:32009L0072 (accessed on 10 July 2020).

19. Directive 2009/73/EC of the European Parliament and of the Council of 13 July 2009 Concerning Common Rules for the Internal Market in Natural Gas and Repealing Directive 2003/55/EC. Available online: https: / / eur-lex.europa.eu/legal-content/EN/ ALL/?uri=CELEX\%3A32009L0073 (accessed on 10 July 2020).

20. Third Energy Package. 2009. Available online: https://ec.europa.eu/energy/en/topics/markets-and-consumers/marketlegislation (accessed on 11 November 2019).

21. European Economic and Social Committee (EESC). Opinion of the European Economic and Social Committee 'for Coordinated European Measures to Prevent and Combat Energy Poverty'. Off. J. Eur. Union 2013, 56, 1-8.

22. Energy Policy of Poland until 2040 (EPP2040). Available online: https: / $/$ www.bing.com $/$ search?q=Energy+Policy $+2040+\&$ form $=$ ANNTH1\&refig=c3e3d56b41934906b738fbce430e7e56 (accessed on 10 March 2021).

23. Energy Policy of Poland until 2030. Available online: https:/ / www.cire.pl/item,38932,2,0,0,0,0,0,polityka-energetyczna-polskido-2030-roku.html (accessed on 10 April 2021).

24. Energy Policy of Poland until 2025. Available online: https:/ / www.cire.pl/item,15970,2,0,0,0,0,0, polityka-energetyczna-polskido-2025-roku.html (accessed on 10 April 2021).

25. Energy Policy of Poland until 2020. Available online: https://www.cire.pl/item,800,2,0,0,0,0,0,zalozenia-polityki-energetycznejpolski-do-2020-roku---skorygowane-zalozenia-przyjete-przez-rade-ministrow-2-kwietnia-2002r.html (accessed on 10 April 2021).

26. Clean Energy for all Europeans. Available online: https://ec.europa.eu/energy/topics/energy-strategy/clean-energy-alleuropeans_en (accessed on 10 March 2021).

27. Sen, A. Development as Freedom; Oxford University Press: Oxford, UK, 1999; pp. 22-23.

28. Brock, G. Global Justice a Cosmopolitan Account; Oxford University Press: New York, NY, USA, 2009; pp. 18-20.

29. Archibugi, D.; Held, D. Cosmopolitan Democracy: Paths and Agents. Ethics International Affairs; Cambridge University Press: Cambridge, UK, 2011; Volume 25, pp. 433-461.

30. Piekut, M. Energy consumption in polish one person households. Energies 2020, 13, 5699. [CrossRef]

31. Kiewra, D.; Szpor, A.; Witajewski-Baltvilks, J. Sprawiedliwa Transformacja Wẹglowa w Regionie Ślaskim. Implikacje dla Rynku Pracy; IBS Research Reports 2019; Instytut Badań Strukturalnych: Warszawa, Polska, 2019; pp. 32-39.

32. Structural Change in Coal Phase-Out Regions. Available online: https://www.espon.eu/sites/default/files/attachments/ Policy\%20Brief\%20structural\%20change\%20in\%20coal\%20phase-out\%20regions.pdf (accessed on 10 March 2021).

33. Uchwała w Sprawie "Polityki Energetycznej Polski do 2040 r". Available online: https://www.gov.pl/web/polski-atom/ uchwala-w-sprawie-polityki-energetycznej-polski-do-2040-r (accessed on 10 March 2021).

34. Aceleanu, M.I.; Pociovalisteanu, D.M.; Serban, A.C.; Grecu, E. The link between environment and employment for a sustainable development. In Proceedings of the International Scientific Symposium, Information Society and Sustainable Development, Azuga, Romania, 24-25 April 2015.

35. Babonea, A.M.; Joia, R.M. Transition to a green economy-A challenge and a solution for the world economy in multiple crisis context. Theor. Appl. Econ. J. 2012, 10, 90-101.

36. United Nations Environment Programme (UNEP). Towards a Green Economy: Pathways to Sustainable Development and Poverty Eradication. Available online: http: / / sustainabledevelopment.un.org /index.php?page=view\&type=400\&nr=126\&menu=35 (accessed on 17 January 2015).

37. International Labour Organization (ILO). What is a Green Jobs? Available online: http://www.ilo.org/global/topics/green-jobs/ news/WCMS_220248/lang--en/index.htm (accessed on 14 December 2014).

38. United Nations Environment Programme; International Labour Organization; International Organisation of Employers; International Trade Union Confederation. Green Jobs: Towards Decent Work in a Sustainable, Low-Carbon World. 2008. Available online: https://www.greengrowthknowledge.org/sites/default/files/downloads/resource/Green_Jobs_Towards_Decent_ Work_in_a_Sustainable\%2C_Low-Carbon_World_Worldwatch_Institute_0.pdf (accessed on 29 April 2021).

39. Low-Carbon World. Available online: http://www.unep.org/PDF/UNEPGreenJobs_report08.pdf (accessed on 14 December 2014).

40. Thomson, H.; Snell, C.; Liddell, C. Fuel poverty in the European Union: A concept in need of definition? People Place Policy 2016, 10, 5-24. [CrossRef]

41. Karpinska, L.; Śmiech, S. Breaking the cycle of energy poverty. Will Poland make it? Energy Econ. 2021, 94. [CrossRef]

42. Alves Dias, P.; Kanellopoulos, K.; Medarac, H.; Kapetaki, Z. EU Coal Regions: Opportunities and Challenges Ahead; Publications Office of the European Union: Luxembourg, 2018. [CrossRef]

43. Sulich, A.; Zema, T. Green jobs, a new measure of public management and sustainable development. Eur. J. Environ. Sci. 2018. [CrossRef] 